7. Reprod. Fert. (1968) 17, 433-442

\title{
ON THE MECHANISM OF ACTION OF INTRA- AMNIOTIC HYPERTONIC SALINE TREATMENT IN RABBITS
}

\author{
D. G. PORTER, * R. BECKER $\dagger$ AND A. GSAPO \\ Washington University, School of Medicine, \\ St. Louis, Missouri
}

(Received 14th December 1967)

\begin{abstract}
Summary. A study was made into the effects of hypertonic saline upon the intra-uterine pressure in non-pregnant and pregnant rabbits. In non-pregnant rabbits intra-luminal administration of hypertonic saline caused an almost immediate transient increase in amplitude and frequency of uterine pressure cycles, a response which was abolished by prior treatment with progesterone. In pregnant rabbits, provided all placentae were damaged by the treatment, intra-amniotic administration of $20 \% \mathrm{NaCl}$ resulted in abortion of all foetuses in $56 \pm 7 \cdot 3 \mathrm{hr}$ SE. If one conceptus escaped damage pregnancy was not interrupted. Furthermore, treatment with $25 \mu \mathrm{g}$ /day oestradiol propionate prevented abortion. Of the procedures carried out, only dislocation of the placentae also caused abortion, whereas pregnancy was not terminated by extra-amniotic administration of hypertonic saline, by cutting the umbilical cords (i.e. causing foetal death), nor by the intra-amniotic administration of normal $(0.9 \%)$ saline. The abortion produced by both intra-amniotic hypertonic saline and dislocation of the placentae could be prevented by oestrogen administration, but not if ovariectomy were combined with placental dislocation. From these results, it is concluded that intra-amniotic hypertonic saline induced abortion in rabbits by interrupting the luteotrophic function of the placenta which resulted in loss of the luteal function essential for the defence of pregnancy.
\end{abstract}

\section{INTRODUCTION}

The instillation of hypertonic saline into the amniotic sac is used as a method of terminating pregnancy in women, although the mechanism by which this procedure induces abortion is disputed. Csapo (1961) suggested that the abortion is produced by a reduction in progesterone secretion consequent upon structural damage to the placenta caused by the saline. However, claims that extensive necrosis of the placenta follows intra-amniotic hypertonic saline administration (Csapo \& Lloyd-Jacob, 1962; Bengtsson \& Csapo, 1962; Straus,

* Present address: Department of Physiology, Royal Veterinary College, Royal College Street, London, N.W.1.

$\dagger$ Fellow, Washington University Medical Student Research Fellowship Program. 
1963; Wynn, 1965; Friedrich, personal communication) have been contested (Christic, Anderson, Turnbull \& Beck, 1966). Furthermore, whereas the steroid chemical analyses of Wiest, Kerenyi \& Csapo (1966) and Wiest (1967) document that a fall in blood-progesterone occurs following intra-amniotic saline, those of Short, Wagner, Fuchs \& Fuchs (1965), Kerr, Roy, Harkness, Short \& Baird (1966) and Klopper, Turnbull \& Anderson (1966) do not support this hypothesis.

An alternative suggestion that abortion is precipitated by a direct action of saline upon the myometrium, has been advanced by King, Friedman \& Steer (1964) and Kerr et al. (1966). Other possible mechanisms such as the release of oxytocin through stimulation of the supra-optic nucleus by an elevated blood-sodium concentration, have been reviewed recently (Fuchs, 1967).

Rabbits offered unique advantages for a study of the mechanism of salineinduced abortion. The evolution of uterine activity in pregnant rabbits has been extensively described (Csapo \& Takeda, 1965; Fuchs, 1964; Porter \& Schofield, 1966; Ogata \& Csapo, unpublished data). Furthermore, the rabbit, being polytocous, has more than one amniotic sac, and is dependent upon an extra-uterine (corpus luteum) as well as an intra-uterine (placenta) endocrine organ for the maintenance of pregnancy. These features permitted the control of values which would have been impossible in the human female.

\section{MATERIALS AND METHODS}

\section{Non-pregnant rabbits}

In a group of ten, non-pregnant New Zealand White rabbits (3.5 to $4.5 \mathrm{~kg}$ ) laparotomies were carried out aseptically under pentobarbitone (100 to 150 $\mathrm{mg}$ i.v.) and ether anaesthesia. Finger-cot balloons of 13-ml capacity, unstretched and attached to polyethylene tubes were inserted, by way of an incision in the vaginal wall and through the cervix into the uterine horns. Balloons were placed in both horns in four animals and in one horn in six animals. Perforated catheters were introduced into the uterine cavity together with the balloons, to permit the intra-uterine administration of saline (Porter, 1968). Each balloon-and-catheter was anchored in the uterus by means of a suture which did not occlude the uterine lumen. The animals were ovariectomized to standardize their endocrine states. The laparotomy wound was closed and the connecting tubes and catheters passed subcutaneously to the back of the neck, brought to the exterior and anchored.

The recording balloons in all animals were filled with water to a volume of 2 to $10 \mathrm{ml}$ (depending upon the size of the uterus) to stretch the myometrium, and thereby induce high myometrial activity ( 25 to $85 \mathrm{~mm} \mathrm{Hg}$ intra-uterine pressure).

Each animal was given an injection of 2.0 to $5.0 \mathrm{ml}$ (depending upon the size of the uterus) of $10 \% \mathrm{NaCl}$ solution into the uterine lumen through the perforated catheter. $(10 \% \mathrm{NaCl}$ was used in an attempt to compensate for the dilution which occurs in the amniotic fluid when $20 \% \mathrm{NaCl}$ is injected into the amniotic sacs of pregnant rabbits.) In two animals the injection was performed $18 \mathrm{hr}$ after treatment with $5 \mathrm{mg}$ progesterone (intra-muscularly) to 
suppress the high activity. Intra-uterine pressure was recorded throughout the experiments by means of Sanborn pressure transducers (No. 267 BC) and pen recorders (No. 321). The records obtained were analysed for changes in the mean amplitude of the active pressures (AP) (i.e. the cyclic pressure changes in excess of $10 \mathrm{~mm} \mathrm{Hg}$ superimposed upon the resting pressures).

\section{Pregnant rabbits}

A group of fifty-one pregnant (25 to 27 days) New Zealand White rabbits was studied. One rabbit, i.e. the 'monitor' rabbit, in each experimental group was equipped with a small (1.5-ml capacity) balloon inserted between the foetal membranes and the endometrium through an incision in the uterine wall of the lower segment. Intra-uterine pressure was recorded as described above.

Experiment I. Intra-amniotic saline. In twenty-eight rabbits all conceptuses were injected with 2.5 to $5.0 \mathrm{ml}$ saline. These rabbits were divided into two groups:

(a) Hypertonic saline: Twenty-two rabbits (experimental) received intraamniotic injections of hypertonic saline $(20 \%)$. Of these, five were given oestradiol propionate ( $25 \mu \mathrm{g} / \mathrm{day})$ following saline treatment for 3 days. Pilot experiments had shown that the administration of more than $30 \mathrm{ml}$ of $20 \%$ $\mathrm{NaCl}$ to rabbits frequently resulted in death. Therefore, in six rabbits where the litter size exceeded six or seven, it was reduced by emptying one uterine horn.

(b) Isotonic saline: Six (control) rabbits received intra-amniotic injections of isotonic $(0.9 \%)$ saline. In three animals with litters exceeding six, one uterine horn was emptied, as a control for the procedure carried out in group (a).

Experiment II. Placental dislocation. In twelve rabbits, all placentae were dislocated by pressure between finger and thumb during laparotomy. In three, bilateral ovariectomy was also performed. Oestrogen therapy (25 $\mu$ g oestradiol propionate daily s.c. for 4 days) was instituted after surgery in the ovariectomized rabbits and in four in which only placental dislocation had been performed.

Experiment III. Extra-amniotic saline. Six rabbits were equipped with perforated catheters, similar to those used in non-pregnant animals. The catheters were inserted, through a small incision in the uterine wall, between the foetal membranes and the endometrium throughout the length of each horn. Twentyfour hours after surgery hypertonic saline $(20 \% \mathrm{NaCl})$ was injected through the catheters, into each uterine horn $(2.5$ to $5.0 \mathrm{ml} /$ conceptus $)$.

Experiment IV. Cutting the umbilical cords. In five rabbits, small incisions were made in the uterine wall over each conceptus and the umbilical cords severed.

Animals in all experiments were repeatedly observed and, after deliveries, the foetuses were examined and weighed. The monitor animals, equipped with recording balloons, were used to obtain an indication of the intra-uterine pressure changes which followed the various procedures, and of the responses to a test dose of 50 m.u. oxytocin (Syntocinon) injected intravenously at various intervals. 
Histology

Specimens of uterus (two) and placenta (eight) were obtained from animals in Expts. I, III and IV. They were fixed in buffered formalin at $4^{\circ} \mathrm{C}$, sectioned at $5 \mu$, and stained with haematoxylin and eosin. In addition, the conceptuses in one horn of a rabbit were treated with hypertonic saline, while those in the other horn received an equal volume of physiological saline. The animal was killed $24 \mathrm{hr}$ after treatment and specimens of placenta were obtained from the two horns. These were fixed in Bouin's fixative and prepared for histological examination as described above.

\section{RESULTS}

\section{Non-pregnant rabbits}

In non-pregnant rabbits the intra-luminal instillation of hypertonic saline caused an increase in both the active pressure (AP) and the frequency of pressure cycles, within 15 min of administration (P1. 1, Fig. 1). This increase in activity reached a maximum in about $30 \mathrm{~min}$ and subsequently declined to pre-treatment values in 50 to $60 \mathrm{~min}$. The AP remained at the pre-treatment level for at least $24 \mathrm{hr}$ after recovery. No response was elicited by the injection of a similar volume of isotonic saline.

The increase in AP was often accompanied by a rise in the resting pressure (five out of eight cases). In four cases there was an increase in the number of irregularly shaped pressure cycles recorded.

In the animals treated with progesterone the administration of hypertonic saline produced only a slight increase in resting pressure, upon which were superimposed a few pressure cycles of less than $10 \mathrm{~mm} \mathrm{Hg}$ (Pl. 1, Fig. 2).

\section{Pregnant rabbits}

Experiment I. Intra-amniotic saline. Of the sixteen rabbits which only received intra-amniotic injections of hypertonic saline, nine aborted all foetuses, dead, in an average of $56 \mathrm{hr}( \pm 7.3 \mathrm{hr}$ S.E. ) after treatment (Text-fig. 1). The tracing of intra-uterine pressure from the monitor rabbit in this group (Pl. 2, Fig. 3), shows an initial response to the saline injection and surgical interference, in the form of a slight increase (less than $10 \mathrm{~mm} \mathrm{Hg}$ ) in AP, which diminished within $8 \mathrm{hr}$. No distinct oxytocin response was detected at 0 and $8 \mathrm{hr}$. After $24 \mathrm{hr}$, the AP had increased to about $15 \mathrm{~mm} \mathrm{Hg}$ and the oxytocin response was marked.

Five rabbits failed to abort and either delivered at term spontaneously or were autopsied. This group maintained pregnancy for an average of $127 \mathrm{hr}$ $( \pm 23.5 \mathrm{hr}$ ) (Text-fig. 1) despite the interruption of two pregnancies, shortly before term, by autopsy. In all cases in this group, at least one living foetus was delivered or found in utero at autopsy.

The two remaining rabbits treated with hypertonic saline alone, each aborted only one foetus, at 50 and $64 \mathrm{hr}$ after treatment, respectively. Neither delivered additional foetuses despite attempts to induce delivery at term with doses of up to 1.5 units of oxytocin, intravenously. At autopsy, both animals had grossly abnormal uteri, with areas of necrosis, possibly caused by leakage 
PLATE 1

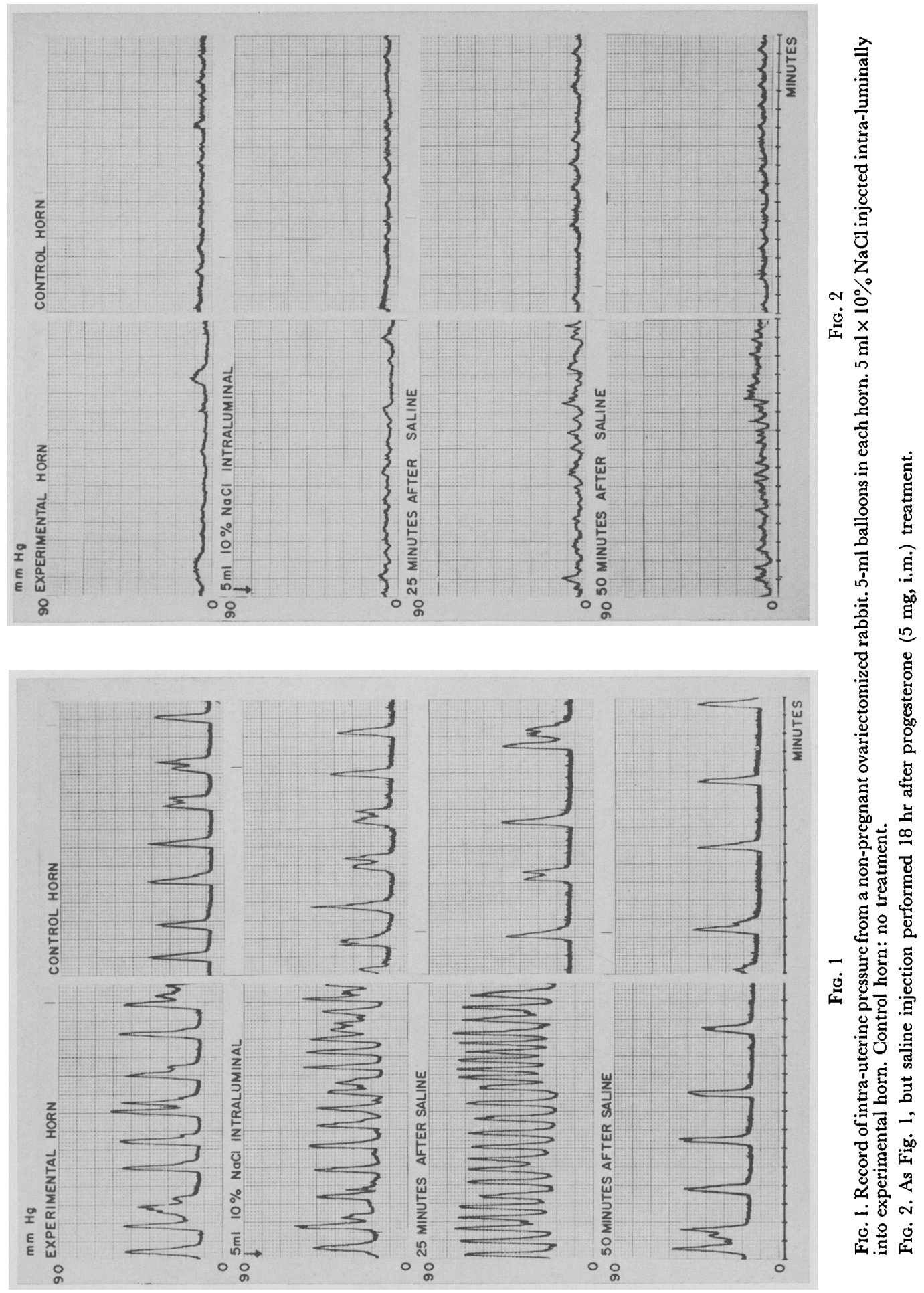

(Facing p. 436) 
PLATE 2

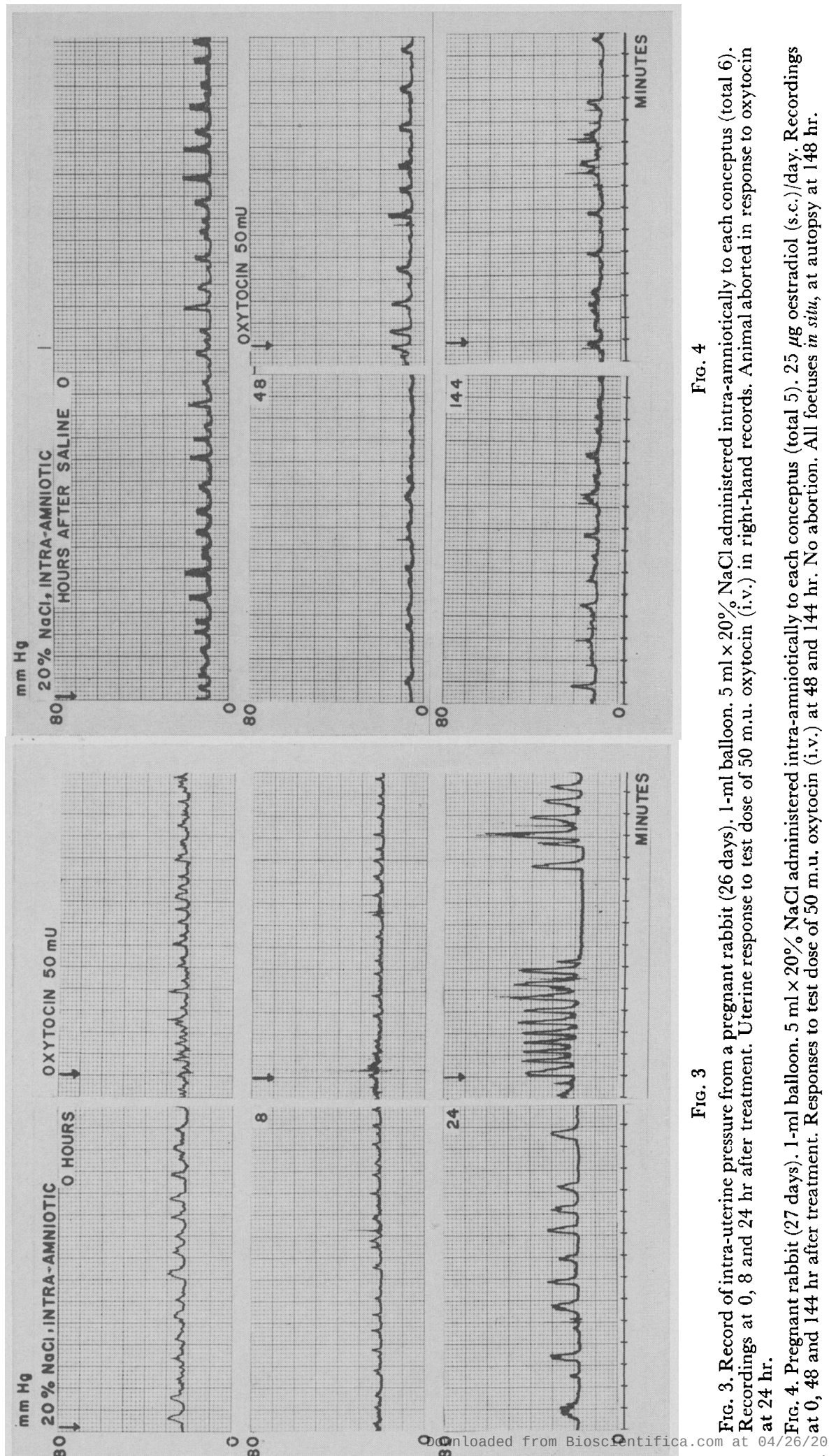

anloaded from Bioscantifica,com at 04/26/2023 10:45:23AM 
PLATE 3
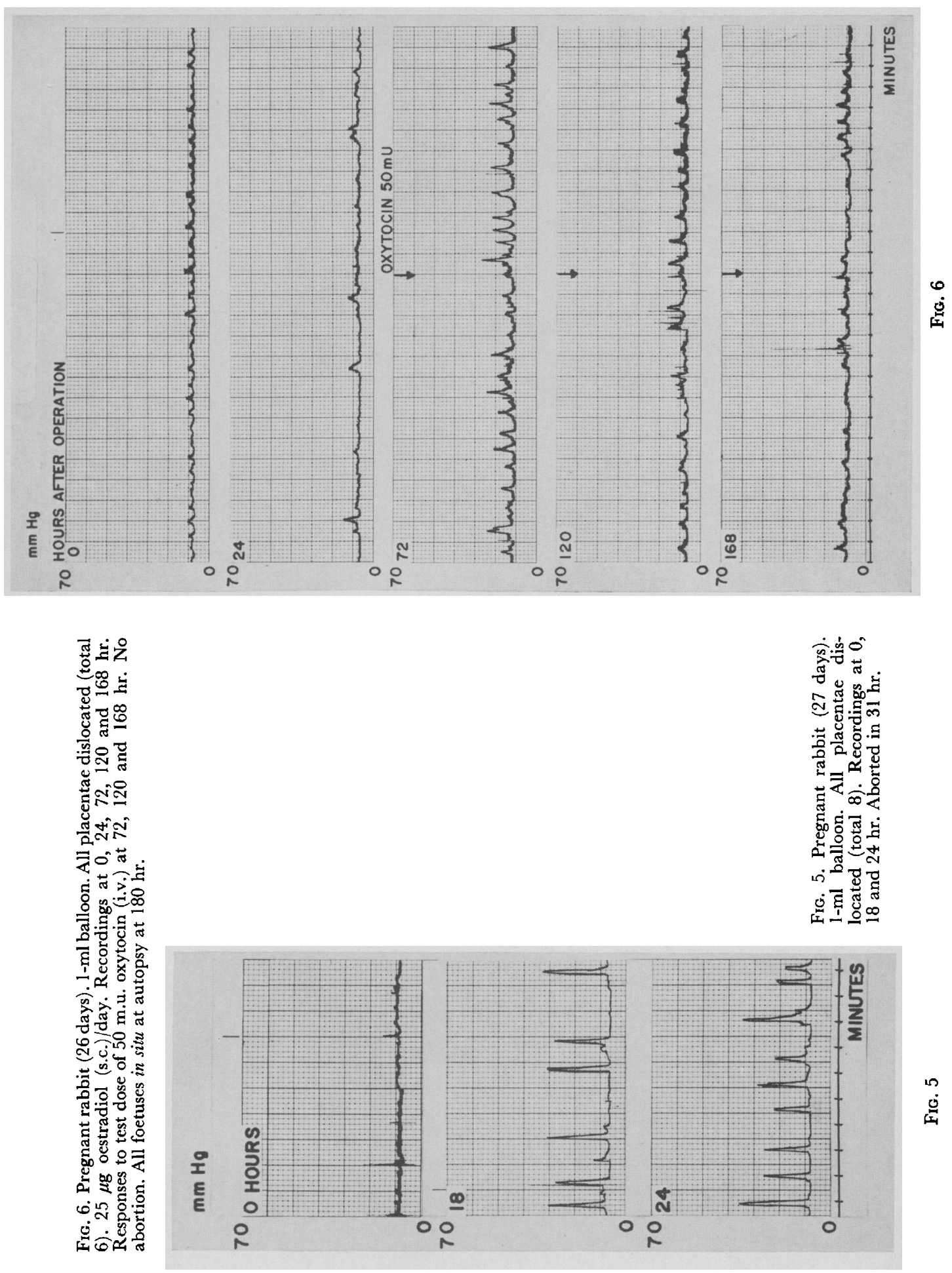
PLATE 4

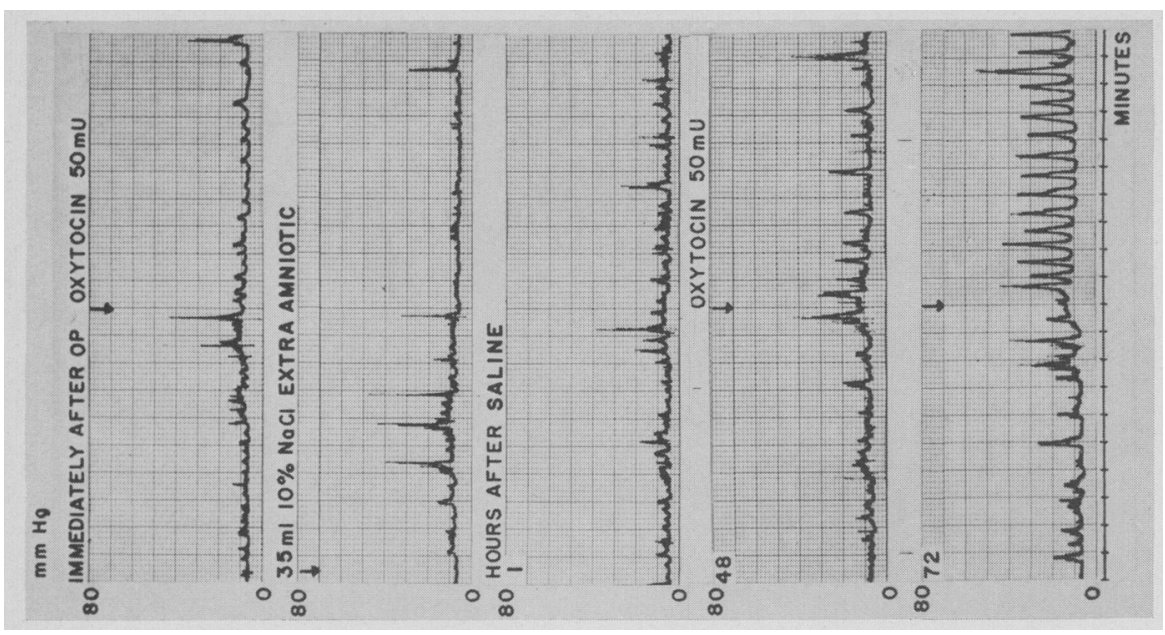

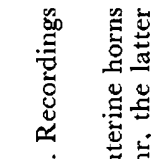

$\infty$ 离 寻吉

过

(i).$:$

온

हुํㅠ

范

on ह

领至

نं

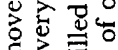

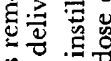

롱.

त्ठ

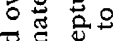

ส.

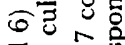

สี

胥

ठ艹

ชูำ

它

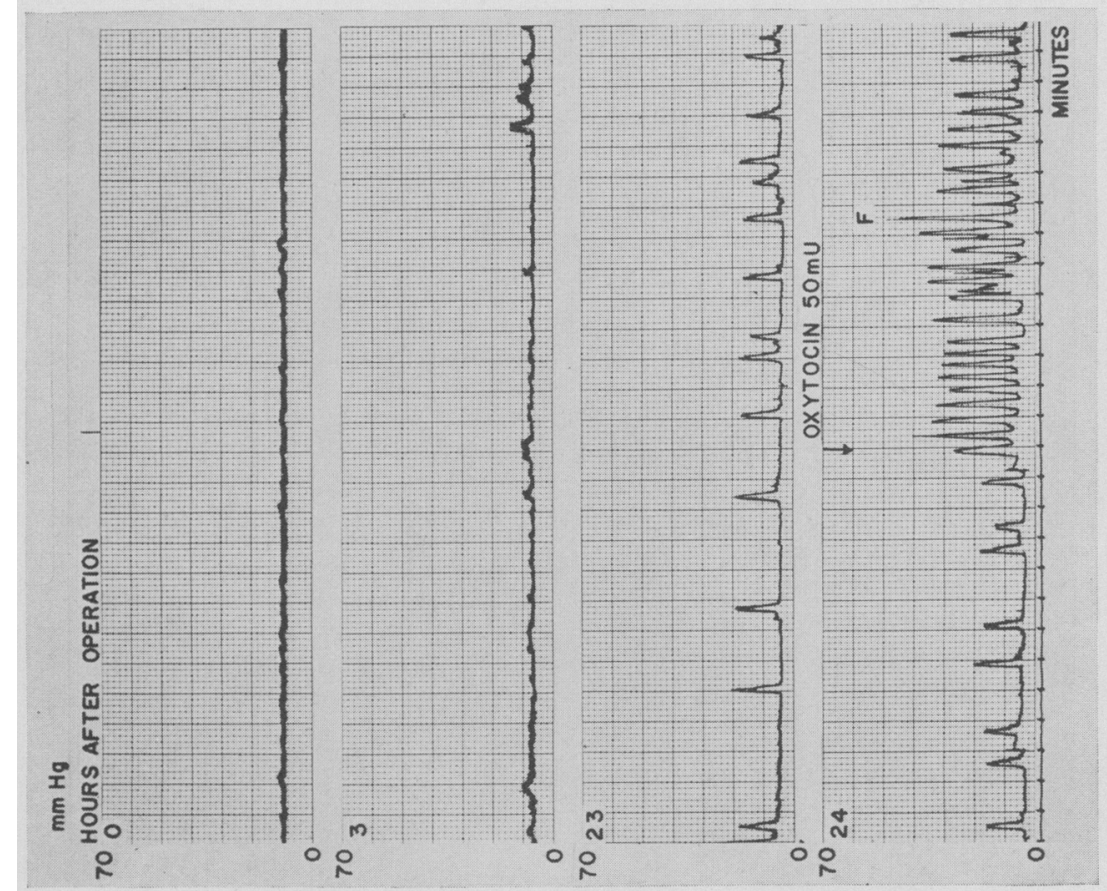

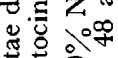

范实-

远 $\times 0$

至

दह की

हूँ

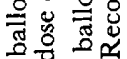

है 范完

뭉

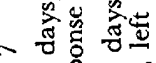

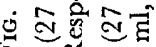

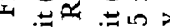
융

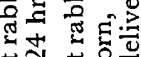

式吉语

ฮี ซ్

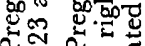

Nल $\infty$ है.

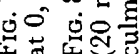


of hypertonic saline over the serosal surface. These two cases are considered as abnormal and their results disregarded.

The six rabbits treated with hypertonic saline and subsequently given oestrogen injections, maintained pregnancy to term, or beyond (i.e. for an average of $129.6 \mathrm{hr} \pm 10 \cdot 7 \mathrm{hr}$ after saline treatment). Intra-uterine pressure of the monitor rabbit of this group, increased slightly after surgery, but subsided within $48 \mathrm{hr}$ (Pl. 2, Fig. 4). Slight responses to oxytocin were recorded up to $144 \mathrm{hr}$ but these did not culminate in delivery. At autopsy it was found that conceptuses of these six animals were separated by annular constrictions of the uterus.

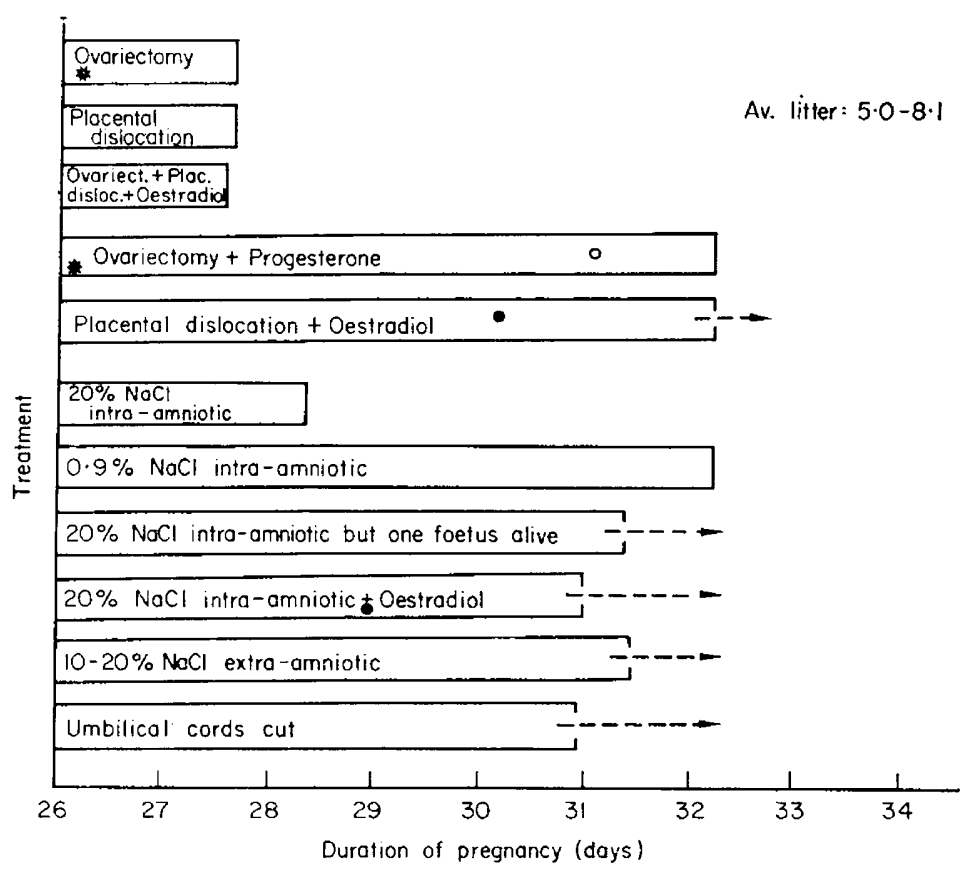

Text-Fig. 1. Summary of data. *Data supplied by courtesy Ogata \& Csapo (unpublished). Oestradiol $(25 \mu \mathrm{g} /$ day $)$ withdrawn at $\bullet$; progesterone $(5 \mathrm{mg} /$ day $)$ withdrawn at $\bigcirc$. Closed columns: all deliveries completed; open columns: some pregnancies interrupted by autopsies.

The six animals which received intra-amniotic injections of normal saline, maintained pregnancy until term (i.e. for $158 \mathrm{hr} \pm 12 \cdot 25 \mathrm{hr}$ S.E. after treatment). Thirty-three foetuses were born alive out of a total of forty-nine.

Experiment II. Placental dislocation. The five rabbits subjected to dislocation of the placentae alone, and the three rabbits in which placental dislocation and ovariectomy were performed, aborted in $31 \mathrm{hr}( \pm 4 \cdot 1 \mathrm{hr}$ S.E. $)$ and $38 \mathrm{hr}$ $( \pm 7.9 \mathrm{hr}$ S.E.), respectively. Tracings from monitor rabbits from both of these categories show that intra-uterine pressure increased rapidly following surgery, and reached $20 \mathrm{~mm} \mathrm{Hg}$, AP, within $24 \mathrm{hr}$ (Pl. 3, Fig. 5 and Pl. 4, Fig. 7). In the ovariectomized monitor rabbit (Pl. 4, Fig. 7), the response to oxytocin at $24 \mathrm{hr}$ culminated in delivery. 
The four animals treated with oestradiol propionate after placental dislocation did not abort (Text-fig. 1). Autopsy, performed on average $150 \mathrm{hr}( \pm 13.5$ hr S.E.) after surgery, confirmed that all foetuses had been retained, macerated, in utero, and were separated by annular constrictions of the uterus. The pressure tracing from the monitor animal showed that no significant uterine activity evolved, even as late as $168 \mathrm{hr}$ after placental dislocation, and that responses to oxytocin were negligible (Pl. 3, Fig. 6).

Experiment III. Extra-amniotic saline. The six rabbits in this experiment maintained pregnancy until term (Text-fig. 1), i.e. on average for $126 \mathrm{hr}( \pm 17.5 \mathrm{hr}$ S.E.) after surgery. In all cases, several living foetuses (twenty-two out of a total of forty-six) were delivered or found at autopsy. Pressure tracings from the monitor animal showed only a slight response to hypertonic saline treatment within $1 \mathrm{hr}$ of instillation and this subsided within $24 \mathrm{hr}$. Distinct but small responses to oxytocin were elicited at 24 and $48 \mathrm{hr}$, and, in this case, the response at $72 \mathrm{hr}$ culminated in delivery (Pl. 4, Fig. 8).

Experiment IV. Cutting the umbilical cords. The five animals in this experiment delivered near to term (Text-fig. 1), on average $102 \mathrm{hr}( \pm 11.5 \mathrm{hr}$ S.E.) after surgery. Examination of all foetuses at delivery confirmed that cord section had been successful.

\section{Statistical analysis}

The numerical data of all experiments were subjected to an analysis of variance (Snedecor, 1956). It was found that the mean treatment-delivery intervals of the following groups: the abortion group of Expt. 1 and the placental dislocation only and placental dislocation + ovariectomy groups of Expt. II were significantly shorter than those of all other groups, at the $5 \%$ level.

\section{Histological examinations}

Specimens of placenta taken from the animals in Expt. I, and from conceptuses treated $24 \mathrm{hr}$ previously with hypertonic saline, revealed extensive areas of necrosis in the labyrinth (Pl. 5, Fig. 9). There was marked loss of basophilia, and of cellular detail. Sections of placenta from animals in Expt. III were either normal in appearance, or showed evidence of necrosis. The normal samples were obtained from conceptuses with living foetuses, whereas those with evidence of necrosis were from conceptuses with dead foetuses. Specimens of placenta obtained $24 \mathrm{hr}$ after treatment with normal saline were nearly normal in appearance (Pl. 5, Fig. 10). A specimen from an animal in Expt. IV contained areas of necrosis in the labyrinth, as well as pockets of nearly normal cells. This specimen was obtained at delivery, whereas all others examined were taken at autopsy before delivery had occurred.

\section{DISCUSSION}

The experiments on non-pregnant animals demonstrate that the intra-uterine administration of hypertonic saline to animals exhibiting a high uterine AP (i.e. stretch-induced) causes a transient increase in myometrial activity. This 


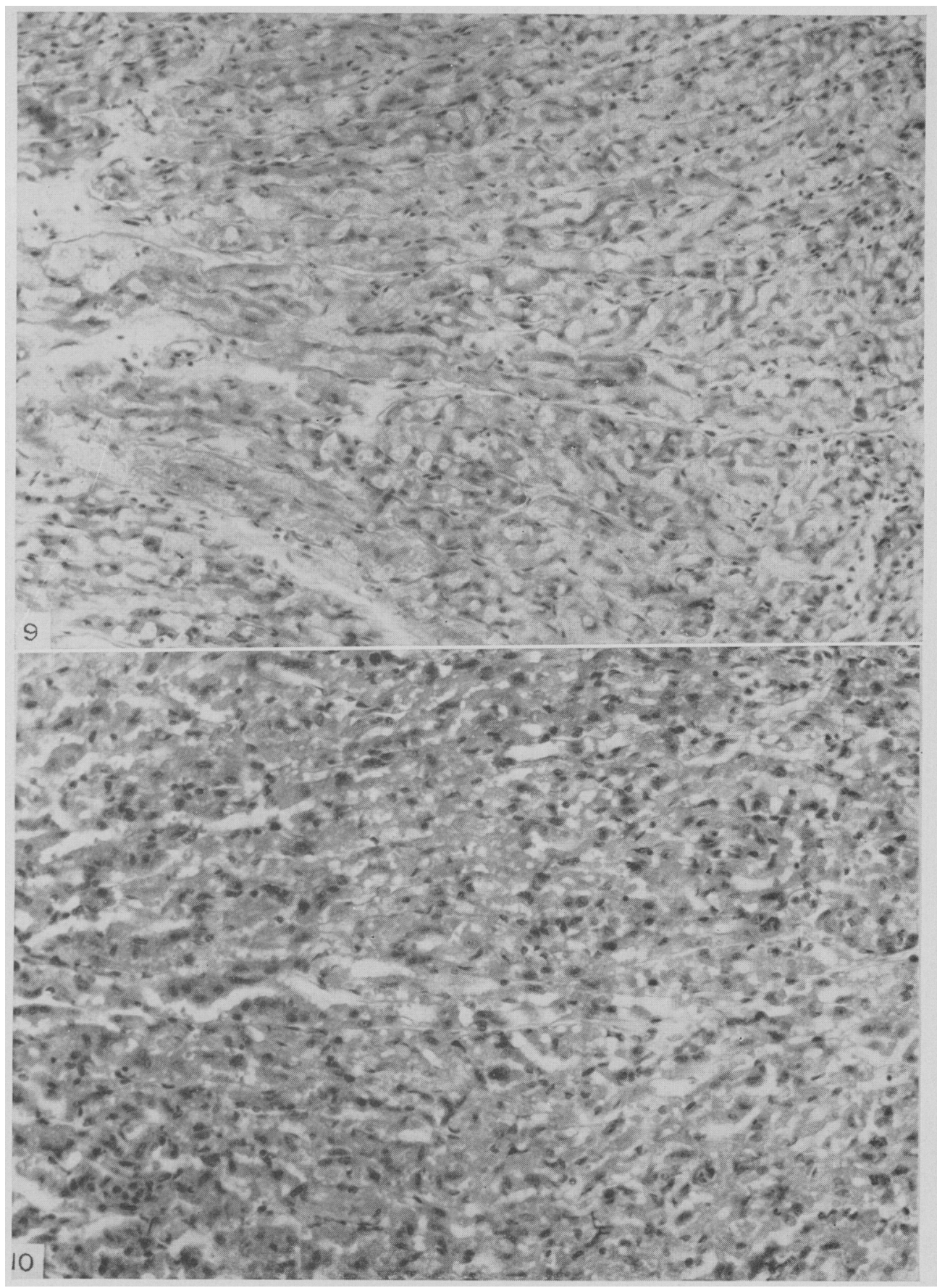

Fir. 9. Scction of placental labyrinth from a rabbit in Expt. la treated with intra-amniotic hypertonic saline. Tissue obtained at autopsy of the animal during abortion. H. \& E. $\times 200$. lis $r$. 10. Section of placental labyrinth from a rabbit in Expt. III. Placenta was obtained at autopsy from a conceptus containing a living foctus. H. \& E. $\times 200$.

(Facing p. 438) 
observation is in agreement with the findings of Wagner (1966a). It is significant that the myometrium recovered quickly (in $1 \mathrm{hr}$ on average) and completely from the effect of saline, and that saline had virtually no effect in progesterone-treated rabbits. An increase in resting pressure, indicative of contracture, and an irregularity in the shape of the pressure cycles were observed in the majority of tracings. These findings suggest that the myometrial response to hypertonic saline was one of dysfunction, which is consistent with the observation of Hendricks \& Tucker (1959) that hypertonic saline causes progressive deterioration of human and rat myometrial activity in vitro, where the hypertonicity remained constant. The transient abnormality of the pressure cycles in the present experiments suggests that, in vivo, the hypertonicity was rapidly eliminated.

The salient feature of the experiments on pregnant rabbits is that abortion was induced only when hypertonic saline was injected successfully into every amniotic sac or when all placentae were dislocated, whereas all other procedures were ineffective. In considering what factors might have caused these abortions it is also necessary to explain the failure of the other procedures to interrupt pregnancy. Possible causative factors include:

A. Extra-uterine: (1) a systemic effect (e.g. increased blood-sodium level) causing a release of oxytocin; (2) surgical trauma.

B. Intra-uterine: (1) direct effect of saline upon the myometrium; (2) foetal death; (3) increase in volume of amniotic fluid; (4) destruction of the placentae.

Considering each possibility in turn, it would seem that release of oxytocin (A.1) is unlikely. Neither extra-amniotic saline treatment (Expt. III), nor the intra-amniotic saline injections, which failed to kill all the foetuses (Expt. Ia), induced abortion, yet all animals in these groups received doses of saline which, when all foetuses died (Expt. Ia), caused abortion.

Surgical trauma (A.2) as the cause of abortion may be eliminated, since animals in Expt. Ib, treated with isotonic saline, underwent similar trauma to those which aborted after hypertonic saline treatment (Expt. Ia). Indeed, the animals treated with isotonic saline (Expt. Ib) delivered $66 \%$ of their foetuses alive, a figure which, in the circumstances, compares favourably with the $76 \%$ observed by Shanklin (1966) in normal deliveries.

It is also improbable that a direct effect of saline upon the myometrium was responsible for the abortions (B.1), since, after both intra- and extra-amniotic saline, only a slight increase in AP was recorded immediately, which subsided within $24 \mathrm{hr}$. In contrast, the activity which culminated in abortion was characterized by a gradual evolution, resembling that previously (Csapo \& Takeda, 1965) and presently (Expt. II) recorded after dislocation of the placentae, although more delayed. It is therefore concluded that the induction of uterine activity by intra-amniotic injection of hypertonic saline in pregnant rabbits and the transient stimulation of AP by intraluminal instillation in non-pregnant rabbits are different phenomena.

Abortion could not be attributed to foetal death alone (B.2), since cutting the umbilical cords failed to cause abortion. This is consistent with veterinary (Arthur, 1964) and obstetric (Csapo, 1967) experience that foetal death in utero does not induce abortion promptly as does, for example, abruptio placentae. 
The possibility that abortion was due to an increase in uterine volume alone is unlikely (B.3). Although an increase in amniotic fluid volume probably occurs following saline treatment, due to the hypertonicity, a similar increase would have occurred in those animals in Expt. Ia where one or more foetuses survived the treatment and where abortion did not ensue. The activation of the myometrium by stretch is an acute phenomenon, and is sustained only if the stretch (i.e. the volume) is maintained (Csapo, Takeda \& Wood, 1963). However, in view of the reports of King et al. (1964) and Wagner (1966b) that the hypertonicity of the amniotic fluid, after saline treatment, is rapidly reduced, it seems unlikely that the increased volume in the present experiments would have persisted long enough (i.e. for $56 \mathrm{hr}$ in Expt. Ia) to account for the abortions.

From the above considerations, it is evident that the first five hypotheses (A.1 and 2, B.1, 2 and 3) fail to explain fully the results of the present experiments. In considering whether placental destruction (B.4) might be responsible for the abortions, several factors should be noted. The results of Expts. II and IV indicate that the integrity of the placenta only is essential for the maintenance of pregnancy since destruction of the whole foeto-placental unit (Expt. II) induces abortion, whereas foetal death alone (Expt. IV) does not. It is assumed that cutting the umbilical cords did not cause the immediate destruction of the placentae, since removal of the foetuses is followed by the delivery of the placentae at term (Klein, 1933; Newton, 1935; Kirsch, 1938; Schofield, 1960) and pockets of nearly normal tissue were found in placentae obtained at term from animals in Expt. IV.

Since oestrogen therapy maintained pregnancy after placental dislocation alone, but not if ovariectomy was performed as well, it can be concluded that the effect of oestrogen, in partially replacing placental function, is mediated through the ovary and not directly upon the myometrium. This observation is consistent with those of Westman \& Jacobsohn (1937), Robson (1937) and Heckel \& Allen (1939) that the life of the corpus luteum (and thus pregnancy) is prolonged in rabbits by oestrogen therapy. Furthermore, the present data support the conclusions of several workers (Klein, 1933; Mayer \& Canivenc, 1953; Schofield, 1960; Greep, 1941; Allen \& Heckel, 1939; Csapo \& LloydJacob, 1961) that the integrity of the placenta is essential for the maintenance of the corpus luteum in the rabbit whereas that of the foetus is not.

Since oestrogen was capable not only of supporting pregnancy after placental dislocation but also after intra-amniotic saline treatment, it would appear that the abortions induced in the present experiments were due largely to a disruption of a luteotrophic function of the placenta. This hypothesis can explain how extra-amniotic saline failed to induce abortion and how, when at least one foetus (and placenta) survived, intra-amniotic treatment was unsuccessful. (The survival of foetuses after intra-amniotic treatment was probably due to the saline being injected extra-amniotically in error.) Also the long injectionabortion time (56 hr) in Expt. Ia, in contrast to the prompt abortions ( $31 \mathrm{hr}$ ) in Expt. II, may indicate that saline requires a definite period of time to cause placental necrosis, whereas placental dislocation causes an abrupt cessation of the luteotrophic function. 
The present data support the conclusion of Csapo (1961) that the successful instillation of hypertonic saline into the amniotic sac initiates the evolution of uterine activity (and hence abortion) by causing a partial withdrawal of progesterone consequent upon necrosis of the placenta.

\section{ACKNOWLEDGMENTS}

This work was supported by grants from the National Institutes of Health (HDO1416, HDO1478 and 5-K6 HD-20, 169) and the Sunnen Foundation. Also we are grateful to the Lalor Foundation, since part of the work was carried out during tenure of a Lalor Research Award by one of us (DGP). Our thanks are due to Miss Elise Gramss for work on the illustrations.

\section{REFERENCES}

AlLEN, W. M. \& HECKEL, G. (1939) Maintenance of pregnancy by progesterone in rabbits castrated on the 11 th day. Am. F. Physiol. 125, 31.

ARthur, G. H. (1964) Wright's veterinary obstetrics, 3rd edn. Ballière, Tindall, Cox, London.

Bengtsson, L. Ph. \& Csapo, A. I. (1962) Oxytocin response, withdrawal and reinforcement of defense mechanism of the human uterus at midpregnancy. Am. 7. Obstet. Gynec. 83, 1083.

Christie, J. L., Anderson, A. B., Turnbull, A. C. \& Beck, J. S. (1966) The human placenta and membranes: a histological and immunofluorescent study of the effects of intra-amniotic injection of hypertonic saline. 7. Obstet. Gynaec. Br. Commonw. 73, 399.

Csapo, A. (1961) Defence mechanism of pregnancy. In: Progesterone and the Defence Mechanism of Pregnancy, Ciba Foundation Study Group, No. 9, p. 3. Churchill, London.

CsAPo, A. I. (1967) The termination of pregnancy by the intra-amniotic injection of hypertonic saline. Yearbook of Obstetrics (1966-67). Ed. J. P. Greenhill. Year Book Medical Publishers, Chicago.

Csapo, A. I. \& Lloyd-Jacob, M. A. (1961) Delayed and prolonged labor, placental retention, and haemorrhages in rabbits. Am. 7. Obstet. Gynec. 82, 1349.

Csapo, A. I. \& LLOYd-JACOB, M. A. (1962) Placenta, uterine volume, and the control of the pregnant uterus in rabbits. Am. 7. Obstet. Gynec. 83, 1073.

CsApo, A. I. \& TAKEDA, H. (1965) Effect of progesterone on the electrical activity and intrauterine pressure of pregnant and parturient rabbits. Am. 7. Obstet. Gynec. 91, 221.

Csapo, A. I., TAKEDA, H. \& Wood, G. (1963) Volume and activity of the parturient rabbit uterus. Am. F. Obstet. Gynec. 85, 813.

Fuchs, A. R. (1964) Oxytocin and the onset of labor in rabbits. 7. Endocr. 30, 217.

Fuchs, F. (1967) Termination of pregnancy by intra-amniotic injection of hypertonic solutions. In: Advances in Obstetrics and Gynecology, chap. 19. Eds. S. L. Marcus and C. G. Marcus. Williams \& Wilkins, Baltimore.

GREEP, R. O. (1941) Effects of hysterectomy and of oestrogen treatment on volume changes in the corpora lutea of pregnant rabbits. Anat. Rec. 80, 465.

Heckel, G. P. \& Allen, W. M. (1939) Maintenance of the corpus luteum and inhibition of parturition in the rabbit by injection of estrogenic hormone. Endocrinology, 24, 137.

Hendricks, C. H. \& Tucker, J. (1959) Direct effects of hypertonic sodium chloride on spontaneous contractility in human and rat myometrium. Am. 7. Obstet. Gynec. 78, 13.

Kerr, M. G., Roy, E. J., Harkness, R. A., Short, R. V. \& Baird, D. T. (1966) Studies of the mode of action of intra-amniotic injection of hypertonic solutions in the induction of labor. Am. $\mathcal{J}$. Obstet. Gynec. 94, 214.

King, T. M., Friedman, G. \& Steer, G. M. (1964) Electrolyte changes following trans-abdominal intra-ovular injection of hypertonic saline. Bull. Sloane Hosp. for Women, 10, 14.

KIRSGH, R. E. (1938) A study of the control of the length of gestation in the rat with notes on maintenance and termination of gestation. Am. F. Physiol. 122, 86.

KLEIN, M. (1933) Sur l'ablation des embryons chez la lapine et sur les facteurs qui déterminent le maintien du corps jaune pendant la deuxième partie de la grossesse. C.r. Soc. Biol., Paris, 113, 441.

Klopper, A. I., Turnbull, A. C. \& Anderson, A. B. M. (1966) Changes in steroid hormone excretion during abortion in mid-pregnancy by the intra-amniotic injection of hypertonic saline. $\mathcal{F}$. Obstet. Gynaec. Br. Commonw. 73, 390.

Mayer, G. \& Canivenc, R. (1953) Moment d'apparition du corps gestatif chez la lapine. C.r. Soc. Biol., Paris, 147, 808. 
Newton, W. H. (1935) Pseudoparturition in the mouse and the relation of the placenta to postpartum oestrus. 7. Physiol., Lond. 84, 196.

Porter, D. G. (1968) The local effect of intra-uterine progesterone treatment. F. Reprod. Fert. 15, 437.

Porter, D. G. \& Schofield, B. M. (1966) Intra-uterine pressure changes during pregnancy and parturition in rabbits. 7. Endocr. 36, 291.

Rosson, J. M. (1937) Maintenance by oestrin of luteal function in hypophysectomized rabbits. $\mathcal{J}$. Physiol., Lond. 90, 145.

Schofield, B. M. (1960) Hormonal control of pregnancy by the ovary and placenta in the rabbit. 7. Physiol., Lond. 151, 578.

Shanki.in, D. R. (1966) Oxytocin induction in pregnant rabbits. Am. 7. Obstet. Gynec. 94, 242.

Short, R. V., WAGNer, G., Fuchs, A. R. \& Fuchs, F. (1965) Progesterone concentrations in uterine venous blood after intra-amniotic injection of hypertonic saline in midpregnancy. Am. 7. Obstet. Gynec. 91, 132.

Snedecor, G. W. (1956) Statistical methods. Iowa State College Press, Ames.

Straus, L. (1963) Report. In: Initiation of Labor, Public Health Service Conference, Princeton, N.J.

WAGNER, G. (1966a) Changes in myometrial activity following intrauterine injection of hypertonic saline. 7. Reprod. Fert. 12, 405.

WAGNER, G. (1966b) Induction of abortion or labor by intra-amniotic injection of hypertonic solutions. Clin. Obstet. Gynec. 9, 520.

Westman, A. \& Jacobsohn, D. (1937) Über Oestrin-Wirkungen auf die Corpus-luteum Funktion. Acta obstet. gynec. scand. 17, 13.

Wiest, W. G. (1967) Estimation of progesterone in biological tissues and fluids from pregnant women by the double isotope derivative assay. Steroids, 10, 279.

Wiest, W. G., Kerenyi, T. \& Csapo, A. I. (1966) Progesterone and the induction of labor with hypertonic solutions. Obstet. Gynec., N.Y. 27, 589.

WYNN, R. M. (1965) Electron-microscopic contributions to placental physiology. 7. Obstet. Gynaec. Br. Commonw. 72, 955. 